\title{
(NON) HUMAN(IMAL) RIGHTS: DISMANTLING THE SEPARATENESS IN LAW AND POLICY
}

\author{
AMY P. WILSON ${ }^{1}$ \\ ${ }^{1}$ Animal Law Reform South Africa; Center for Animal Law Studies at Lewis \& Clark Law School, 10015 \\ SW Terwilliger Blvd \#7768, Portland, OR 97219, USA. ORCID: 0000-0001-6707-9866, Email: amywil- \\ son@animallawreform.org
}

ABSTRACT: In 2016, the South African Constitutional Court recognised that the guaranteed human right to the environment, as contained in the Constitution, includes animal welfare. In its judgment, the court stated that the suffering of individual animals is correctly linked to conservation and that this "illustrates the extent to which showing respect and concern for individual animals reinforces broader environmental protections. Animal welfare and animal conservation together reflect two intertwined values". Although the effect of the statement by the highest court in the land is yet to be fully realised, the court unambiguously demonstrated in its ruling the clear link between human rights and animal interests. These interests are not only to be interpreted in the broad sense relating to species-conservation, but rather the interests and welfare of individual animals.

Building on from this approach and the rationale provided by the court, this Paper looks to explore more broadly the interaction and linkages between human and animal rights and interests. More particularly, it attempts to illustrate how these concepts may reinforce and enrich one another and how this relationship may be better reflected in law and policy. It will argue that sophisticated democracies and movements require an integrational approach. By expanding the scope and interpretation of certain human rights to include animal interests; and through coordinated, targeted efforts - we ensure notion of justice is achieved, for all who require it.

KEYWORDS: human rights, animal rights, integrational approach, law, constitution, integrative approach, social justice 


\section{STATUS QUO}

\section{"I am the king, I can do whatever I want." - Scar ${ }^{1}$}

Human rights, as the name suggests, are the rights granted to members of the homo sapiens species. These are gifted to us as a birthright, with an acknowledgement that "all human beings are born free and equal in dignity and rights" (Universal Declaration of Human Rights, Article 1). We recognise that the "inherent dignity and the equal inalienable rights of all members of the human family is the foundation of freedom, justice and peace in the world" (UDHR, Preamble).

While vast strides have been made in the human rights movement over the last few decades, when one considers the current state of the world, there is not only non-achievement of rights, but clear violations. The stark reality is one of indignity, restriction, discrimination and injustice and a state of social, political, economic, and environmental crisis. In many instances, this is as a result of action or omission by the very bodies meant to respect, protect and promote these rights. We live in a deeply divided society and the consequences of this division and inequality bleed into every facet of daily life.

More so than any other point in our history, our entire survival hangs in the balance. Despite humans being "endowed with reason and conscience" we appear to be disregarding these and to have contempt for our own morality, failing to act "towards one another in a spirit of brotherhood" (UDHR, Article 1).

\section{Separateness}

"Everything you see exists together in a delicate balance. As king, you need to understand that balance and respect all the creatures, from the crawling ant to the leaping antelope." - Mufasa

Putting aside the failures in respect of these rights, they are inevitably constructed by humans, for humans, and no one else. The other inhabitants of our earth are not the bearers of these rights, do not benefit from these and their interests are not acknowledged. The mere fact that they do not belong to this human family has the consequence that their own capacities, needs, worth, consciousness and sentience are rejected from our scope of consideration.

This position is clearly reflected in the majority of behaviors, practices, and im-

\footnotetext{
${ }^{1}$ I have referred to quotes and themes from the movie Disney's The Lion King (2019) throughout, given its recent release at the time of writing and the fact that I believe it provides simplistic yet important messages. Perhaps trivial to an academic audience, it may assist in simplifying some complex issues for a non-academic one. There is a want and need to reach a broader audience and while complex ideas and terminology are recognisably important - in a call for mass change requiring mass action - one needs to connect with an uncomplicated narrative. In addition, I have utilised lions as an example to illustrate some of the overlap with human and animal interests in a theoretical and practical context later on in this Paper.
} 
portantly, legal systems. Generally, nonhumans are not mentioned in the documents grounding the foundation for rights, and in the rare occasion that they are, their reference is one relating to their use or benefit to humans ${ }^{2}$.

Thus, in addition to the existing inequities and distinctions made between our fellow humans, we have drawn a line between ourselves and the remainder of beings on earth. This separating line has allowed our insatiable need to dominate and commodify to thrive - at the expense of everyone and everything around us. The use of both differentiating and euphemistic terms such as "natural resources" and "sustainable use" in relation to animals ${ }^{3}$ has served to further entrench this deep divide and provide justification for our (sometimes abhorrent) actions.

We have been so desensitised to the interests of animals, and have rather, since birth, been led to believe that their wide-scale use and abuse is somehow acceptable. Humans, as the "top of the food chain", may dictate the manner, time and place of the lives and deaths of others.

Every single day, millions of animals around the world are ruthlessly utilised, tortured and violently killed. For the most part, such actions occur largely out of sight, are sanctioned by the legal system ${ }^{4}$ and endorsed by society. We are all complicit in a system that (based purely on numbers) is the most violent and unjust in all of history.

In addition to the first layer of separateness among humans themselves; the second layer among humans and nonhuman animals; there exists a third layer of separateness - the disconnectedness between humans and our own habitat ${ }^{5}$. Earth itself is being destroyed on a daily basis - deliberately, through legal means, and predominantly for commercial gain which benefits very few.

It should be increasingly apparent that this culture of separateness - this "exclusionary approach" - has failed us. Until we explicitly acknowledge the interlinkages between our own interests and the interests of others and stop excluding members of our society from any real consideration - justice in the true sense of the word will never be achieved.

\footnotetext{
${ }^{2}$ Notably, animals are expressly included in certain foreign constitutions in a protective way, such as in the constitutions of Switzerland (1973), India (1976), Brazil (1988), Slovenia (1991), Germany (2002), Luxembourg (2007), Austria (2013), and Egypt (2014). The content of these inclusions differs, but regardless, has still largely failed to meaningfully change the daily realities for animals in these countries who are still utilised and abused in a broad variety of ways.

${ }^{3}$ Including "pork" and "beef" (not pigs or cows) “culling”, “destroying” and "harvesting” (not killing); "game" (not wild animals), and various other terms.

${ }^{4}$ There are of course actions in relation to animals that are considered unlawful and criminal. There is accordingly not carte blanche to simply abuse animals as one wishes. Most jurisdictions at a minimum provide for certain acts of cruelty towards (at least some) animals in legislation, but the majority of laws still allow for arguably cruel practices for certain uses of animals (including for example animals in agriculture), and do not always protect all animals (often excluding fish or invertebrates as a common example).

${ }^{5}$ While the exploration of the disconnectedness between humans and earth is an important idea to explore, it is outside the scope of this Paper.
} 
This Paper

"You have forgotten who you are and so forgotten me. Look inside yourself Simba, you are more than what you have become, you must take your place in the circle of life" - Mufasa

There is, in my view, a fundamental, undeniable link between the interests of humans and of animals. Accordingly, there is a necessity to recognise this in our legal system, policy considerations and activism efforts. With limited scope to cover subject matter which is highly complex and controversial, this Paper attempts a rudimentary introduction to the subject of human rights and animal rights and more specifically the interlinkages between the two. I hope to develop this more rigorously in the future as this issue warrants an in-depth exploration and raises many complex ideas and consequences ${ }^{6}$.

In my experience, the terms "human rights" and "animal rights" are predominantly utilised in two ways in relation to one another. The first is comparatively - with the narrative of "either or". The second is directly contra distinctly with one another - with the narrative of "vs.". Rarely, have I encountered the two terms utilised in a meaningful, inclusive way in relation to one another - with the narrative of "and".

The former two narratives are not sourced only from or utilised by industry or government, but unfortunately, from activists on either "side".

Human rightists rarely include nonhumans in their efforts or work - perhaps due to the fear that this may diminish their work for humans; they may be restricted by a finite number of resources; they may hold a belief that animals are not worthy of inclusion, or other factors. Correspondingly, animal rights activists have a reputation for not caring enough (or at all) about human interests. In fact, animal activism has largely been criticised for almost completely excluding (even being militantly opposed to) human interests. A perfect example to illustrate this principle would be where animal activists celebrate the occasion where a poacher is killed. The loss of this human life (in this instance) is considered somehow beneficial or worthy of rejoice, with little mourning or thought of the broader landscape in which this issue operates ${ }^{7}$.

\footnotetext{
${ }^{6}$ As a passionate activist and budding academic, I realise that some contentious claims are contained herein and may be better articulated than the way that they are. My intention is not to isolate but rather to include. As someone who grew up in post-apartheid South Africa with a privileged life, this has undoubtedly shaped the lens through which I view the world. It has always been apparent to me that separation, oppression and injustice did not end with apartheid. My experiences living in the country have led me to a point where I cannot simply accept the status quo. I therefore must attempt to find a better solution for a divided, inequitable and unjust society. Although I wish to learn and expand on the ideas herein and the paper reflects my personal experiences and views. I have no doubt that these require and warrant more time and proper consideration.

${ }^{7}$ Many may not be aware that poachers may themselves also be victims. These are, in many instances, persons plagued by poverty, lack of education, are also oppressed and also subject to injustice. While the act of poaching is by its nature illegal and not to be sanctioned, the issue is much more complex than the simple commission of a crime.
} 
These failures and separate approaches have, in my view, hampered the progress of both groups in achieving their aims and served to obstruct broader ideas of justice. Those who have benefited (and continue to benefit) from these failures are the oppressors - the common enemies of the notion of justice.

As both a human and animal rights activist, in my animal rights work, I have run into a lot of "whataboutism":

What about homelessness? Or racism? Or sexism? Why are you wasting your time on chickens when so many human beings are suffering?... Whataboutism is a rhetorical strategy meant to paralyze, not persuade. But it works because it plays on a real fear: that compassion is a zero-sum resource, and political capital even more so. The energy we spend on chickens is energy stolen from the opioid epidemic (Klein 2019).

It appears to offend people that I could even consider expending resources on beasts and brutes, when I could (for example) be utilising my knowledge, skills or time for saving children ${ }^{8}$.

Activist capacity excepted, as a lawyer, I have further observed that in legal efforts to further animal protection, human rights and interests are often utilised purely as a means to an end ${ }^{9}$. Thus, where animal protections are lacking in law, human-centric legislation and protections are employed to attempt to benefit animals, although perhaps not with the genuine intention of furthering human protection as well ${ }^{10}$.

With the above observations in mind, there exists major missed opportunities to inter alia combine efforts and resources, particularly when there is a common goal or mutual "enemy" (which is more often than not). Current systems undermine the foundational values on which rights are built and the victims are both nonhuman and human animals.

\footnotetext{
${ }^{8}$ At this point however, my personal view is that my animal activism led me to be a much better advocate for humans. Fighting for rights, justice or against oppression is not a zero-sum game, and it has never been more necessary to expand our circles of compassion and consideration.

${ }^{9}$ This is at least sometimes out of sheer necessity and due to the legal frameworks within which animal protection lawyers must operate. For example - in jurisdictions such as the United States of America - farmed animals are excluded from legal protections (including in some instances, the legislative definition of "animal"). If they are not outright excluded from the definition, farming /traditional "agricultural practices" may be specifically exempted - such as from anti-cruelty provisions. Thus, when these lawyers are aiming to obtain better protections for agricultural animals (as an example), they must rely on utilising the provisions of other legislation or other areas of law. These may include consumer protection law, environmental law, administrative law and other areas aimed at the protection of humans. Furthermore, it is not only the content of laws that are problematic but other legal barriers to obtaining better protection - such as standing requirements to bring animal cases in in the court system itself in the court system itself, barriers to enforcement of laws by government departments, and other issues. ${ }^{10}$ This is obviously not always the case as many organisations are committed to obtaining overall justice. This statement rather refers to ingenuine efforts to utilise human protections to better animal protections with no real concern for the impact that same might have on humans.
} 
Accordingly, it is becoming increasingly important (and I submit absolutely essential) that in the fight for protection of rights and interests of humans and animals (respectively) - these endeavours follow an integrational approach.

While it is apparent that there will be instances when these interests and rights will conflict, this is no reason to discount the other interests $a b$ initio $^{11}$.

If conflict itself was a sufficient basis for the non-consideration of interests or granting of rights, then there would be very few (if any) guaranteed human rights.

Importantly, the law already recognises that rights and interests of individuals will conflict and sets out procedures and mechanisms to deal with the limitation of rights.

Therefore, for purposes of this Paper, I explore at a high level some of the potential ways in which human and animal interests ${ }^{12}$ intersect by utilising specific examples of industries where animal exploitation and suffering are present and legal, and examining how these factors impact on human rights. I then suggest how by including animals and their interests in our scope of consideration, certain human rights may be better achieved ${ }^{13}$. My focus will be on the South African context, although such an approach has extraterritorial application, particularly in constitutional states with values and rights similar to those contained in the South African Constitution. I am further of the view that as a country, it presents a good case study - given its history, current inequalities and the critical role that animals play in its society. My focus will also be narrowly on law and broader policy considerations as compared with some of the higher-level philosophical debates ${ }^{14}$.

I will begin by providing a brief introduction into the nature of rights generally and then specifically within the South African context. I will then explore the foundations of a new integrational approach, with two selected examples of overlapping human and animal interests in practice. I will move to briefly set out some potential difficulties and challenges with the proposed integrational approach and conclude with specific examples of how such approach may potentially be incorporated in legal and activism efforts.

My starting point is that nonhuman animals, like human animals, have intrinsic worth and individual interests and are worthy of protection in their own right ${ }^{15}$.

\footnotetext{
${ }^{11}$ More specifically, the consideration of animal interests and animals as stakeholders in their own right. Human interests and humans as stakeholders are already accepted as worthy of consideration.

${ }^{12}$ I refer to both rights and interests herein on the basis that both humans and animals have interests, however only humans have legally recognised "rights" at this point in time.

${ }^{13}$ This is due to the fact that the exclusion of and complete disregard for animals' interests as well as their current treatment has led to the non-attainment and active violation of guaranteed human rights. ${ }^{14}$ Importantly, I will not be focusing on animals as rights bearers of a specific rights, nor legal persons as such - although personally, I do believe that animals should be rights bearers, and this should be reflected in law. There are various legal efforts to obtain the status of legal persons for animals, to apply constitutional rights directly to animals, as well as other legislative rights to animals. While these are important, this is not my specific focus for this Paper. I will also not be considering further why it is arbitrary not to include them, as I believe this has already been well articulated.

${ }^{15}$ This is a critical point. Although I will be referring substantially to human rights herein and focusing
} 


\title{
THE IDEA OF RIGHTS AND THE NOTION OF JUSTICE
}

\author{
"Life's not fair is it." - Scar \\ Human Animal Rights - Generally
}

Human rights are:

(...) an important tool to hold states, and increasingly non-state actors accountable for violations and also to mobilise collective efforts to develop communities and global frameworks conducive to economic justice, social wellbeing, participation, and equality. Human rights are universal, inalienable, interdependent and indivisible (ESCR 2019).

The above definition highlights a number of important characteristics of rights including accountability for the achievement of rights, as well as their interdependent and indivisible nature.

As a society, we understand that as beings with worth, such worth must be respected; as beings with dignity, we must be treated with such; and as beings with fundamental interests, these must be protected in law to be effective:

[1]aw is the architecture of society; it ensures that society protects its common interests and realizes its goals by influencing behavior; and based on its temporally forward-looking view, law acts now to make possible a certain kind of world and society for the present and for the future (Kotze 2014).

The law is thus the perfect way to influence public behaviour and make changes that have a large impact on society.

Rights (as one of the expression of our interests in law), are not absolute; they are generally qualified and limited. This can be done in the content of the provision itself $^{16}$; through a general limitation clause, and/or through other general principles

on the impact that our treatment of animals has on humans - individual animal interests are implicated in a major way in each and every instance. I wish to emphasise that my argument is not that humans should protect animals because failure to do so harms us. Rather, my starting point is that animals, just as humans, are worthy in their own right of protection, and this is why such interests must also be considered. My goal, however, is to convince even the anthropocentric reader that animal protection is a human rights issue. Traditionally, and in many instances, animal protection has been recorded in law solely for human benefit - for example "to prohibit one legal subject behaving so cruelly to animals that he offends the finer feelings and sensibilities of his fellow humans". (South African case of R v Moato 1947 (1) SA 490.) However, the South African courts have now acknowledged that animals deserve to be protected because they have intrinsic worth and our duties to them have shifted from merely safeguarding human interests. This is more fully as will be set out in further detail below.

${ }^{16}$ One example is the right to freedom of expression in the South African Constitution contained in section 16 of the Bill of Rights. The rights offered by the first paragraph are qualified by the second indicating that the right does not extend to "propaganda for war...incitement of imminent violence... or advocacy of hatred that is based on race, ethnicity, gender or religion, and that constitutes incitement to cause harm.” (South African Constitution 1996: section 16 of Chapter 2). 
(such as that reasonableness $)^{17}$. Rights are broad and meant to act as a base providing a minimum threshold. However, their existence on paper is only the first step, with an intention that they are to be respected, protected, promoted and fulfilled ${ }^{18}$. Rights need to come with action, particularly, when rights contain realisation provisions, these actions include policy and legislative measures, executive actions and through adjudication by the judiciary. As the content and actioning of rights may not be clear, and because the ultimate goal is their achievement - rights need to be interpreted which is a dynamic process, evolving based on the changing needs of society, contextual and other considerations.

\section{The South African Context}

\section{Humans and Rights}

"Oh yes, the past can hurt. But from the way I see it, you can either run from it, or learn from it." - Rafiki

Apartheid (literally translated meaning "separateness") was the system of racial segregation and discrimination that forced different racial groups to live separately, use different facilities and otherwise develop severally (Wilson 2019).

With the end of its tyranny, South Africa was reborn as democratic nation, with its birth certificate - the Constitution. Among its many notable and important aims, the Constitution (and more specifically its predecessor, the Interim Constitution) essentially acted as a bridge to assist us to cross over from our sordid past to a better future ${ }^{19}$. Mureinek notes one of the main goals of this dispensation was a move away from a system of parliamentary sovereignty to one of justification.

Importantly, if the Constitution is a bridge away from a culture of authority, it is clear what it must be a bridge to. It must lead to a culture of justification-a culture in which every exercise of power is expected to be justified; in which the leadership given by government rests on the cogency of the case offered in defense of its decisions, not the fear inspired by the force at its command. The new order must be a community built on persuasion, not coercion (Mureinek 1994:31).

As a constitutional state, this document is the supreme law of the land, the lex

\footnotetext{
${ }^{17}$ In the South African context, the concept of "reasonableness" has arisen in various contexts. For further reading on the subject of rights and their limitations in the South African context particularly reasonableness and proportionality - see Young 2017. The "reasonableness review" also arose in the important South African Constitutional Court case of Grootboom (2000).

${ }^{18}$ This sentiment appears in Section 7 of the Bill of Rights in the South African Constitution "The state must respect, protect, promote and fulfil the rights in the Bill of Rights".

${ }^{19}$ It was the Interim Constitution of 1994 that aspired to be 'a historic bridge between the past of a deeply divided society characterized by strife, conflict, untold suffering and injustice, and a future founded on the recognition of human rights, democracy and peaceful co-existence and development opportunities for all South Africans, irrespective of colour, race, class, belief or sex'. These words appear in the postamble to the Constitution, entitled 'National Unity and Reconciliation'.
} 
fundamentalis. All law must be consistent with it and it is enforced and upheld by the Constitutional Court.

The Preamble to the Constitution states a belief that South Africa belongs to "all who live in it, united in our diversity". It furthermore seeks to establish a society based on democratic values (human dignity, equality and freedom); social justice; and fundamental human rights.

The Bill of Rights contained in Chapter 2 of the Constitution is the cornerstone of democracy in the country. The state must respect, protect, promote and fulfil the rights in the Bill. The rights are not absolute and subject to the limitations - as contained or referred to in section 36, or elsewhere in the Constitution.

Certain rights contain realisation provisions, which, although the wording differs, place an active duty on government to achieve these rights "through reasonable legislative and other measures"20.

Realisation is not straightforward - there are restraints in achieving rights and some can thus only be achieved over time. This is the idea of "progressive realisation" which appears in relation to certain socio-economic rights in the South African Constitution. Notably, in the context of economic, social and cultural rights:

Progressive realization of ESCR does not mean that governments do not have obligations in terms of these rights until a certain level of economic development is reached but rather that there will be continual progress on the status of these rights and therefore states should take deliberate steps immediately and in the future towards the full realization of ESCR (ESCR).

This idea still requires active steps and the utilisation of all available resources to achieve these rights but acknowledges that these are not achieved "overnight".

Another concept of relevance (albeit controversial) is that of "transformative constitutionalism" which entails that the Constitution in South Africa was not designed simply to entrench the status quo: rather, it was enacted for the purpose of fundamentally transforming society ${ }^{21}$.

All courts in South Africa must apply the Constitution and promote the spirit, purport and objects of the Bill. It applies to all law, and binds the legislature, the executive, the judiciary and all organs of state. Section 39 of the Bill of Rights provides guidance on interpreting the Constitution, as do a plethora of cases that have been heard since its inception:

[The Supreme Constitution] is a mirror reflecting the national soul, the identification of the ideals and aspirations of a nation; the articulation of the values bonding its people and disciplining its government. The spirit and tenor of the

\footnotetext{
${ }^{20}$ Examples of rights with these provisions include the rights to housing (section 26); environment (section 24); and health care, food, water and social security (section 27). (As contained in Chap. 2, the Bill of Rights).

${ }^{21}$ Notably, Professor David Bilchitz has written on the idea of transformative constitutionalism specifically in relation to animals. Bilchitz argues that this notion would require the recognition of animals' interests in the Constitution - either through a direct amendment thereto or through an interpretation thereof (Bilchitz 2009).
} 
Constitution must therefore preside and permeate the process of judicial interpretation and judicial discretion (S v Acheson 1991).

While there are various approaches to judicial interpretation, two worthy of mention are the "literal approach" and the "purposive and contextual approach". Without exploring the former, the latter means that the purpose or object of the relevant legislation is the prevailing factor in interpretation. According to certain case law, "a supreme Constitution must be given a generous and purposive interpretation" (Shabalala v The Attorney-General of Transvaal 1995).

This background seeks to illustrate the extremely complex nature of rights, and the need to consistently evaluate their content and realisation, in accordance with the landscape in which they operate. Based on all of these factors and considerations, South Africa may appear to be the ultimate hub of justice. Yet, despite all of these values and promises - the realities for the vast majority of the South African population include poverty, violence, crime, and discrimination. In 2018, the World Bank deemed South Africa as the most unequal ${ }^{22}$ society in the entire world (Time 2019). This illustrates that the divisive system did not end with the new democracy. Further to this, the country's education system ${ }^{23}$ has also been rated as one of the worst in the world (Economist 2017).

The country has an extremely diverse population of approximately 57 million people and 11 official languages. Whilst its unique cultural and belief systems should be celebrated, particularly in the wake of its past, certain policies and laws aimed at addressing inequalities can have the effect of negatively emphasising differences and furthering the societal and racial divide ${ }^{24}$.

Above the societal level, the expectations of an accountable, transparent government and a culture of justification have been met with the reality of corruption and a plethora of political issues.

\section{Nonhuman Animals}

Whilst the societal divide among the human population is largely as a result of a legal system of oppression which officially ended 25 years ago, a legal distinction and system of oppression still exists between humans and nonhumans.

As with most jurisdictions in the world, animals are considered as mere property. They are accounted for in the legal system on the basis of such property status, and "protection" is offered through either anti-cruelty statutes and/or environmentally based statutes dealing with "conservation", "biodiversity" and similar concepts.

Animals are not expressly mentioned in the Constitution, other than in relation to

\footnotetext{
${ }^{22}$ Contrast this with the foundational constitutional value of "equality".

${ }^{23}$ Contrast this with the right to education contained in section 29 of the Bill of Rights.

${ }^{24}$ Examples include black economic empowerment (or broad-based black economic empowerment often referred to as "BEE" and "BBBEE" respectively) and the proposal to amend the Constitution to provide for land expropriation without compensation, neither of which concepts have been expanded on for purposes of this Paper.
} 
which levels of government have competencies to deal with matters relating to them ${ }^{25}$.

The predominant legislation relating to animal protection ${ }^{26}$ was passed nearly 60 years ago and has not undergone significant changes since its promulgation. The current legal inclusion of animals is largely deficient and fails to protect them or their interests in any meaningful way - treating them as commodities and/or tools.

\section{A NOVEL APPROACH}

Human interests and animal interests: inclusive jurisprudence

“Change is good." - Rafiki

In 2016, the Constitutional Court ${ }^{27}$ recognised that the guaranteed human right to the environment, as contained in the Constitution, includes animal welfare. In its holding, the court stated that:

(...) animal welfare is connected with the constitutional right to have the "environment protected through legislative and other means". This integrative approach correctly links the suffering of individual animals to conservation, and illustrates the extent to which showing respect and concern for individual animals reinforces broader environmental protection efforts. Animal welfare and animal conservation together reflect two intertwined value. (NSPCA 2016:58)

This integrative approach referred to by the court in the former quote, recognises the impossibility of simply separating out environmental concerns and concepts from animal welfare and protection for their significant interests. This approach requires an attitude of respect for individuals that make up a whole. This compared with an "aggregative" approach - which involves a focus on overarching holistic goals (i.e. that many individuals may be sacrificed for a wider goal) (Bilchitz 2017).

The court further stated that "the rationale behind protecting animal welfare has shifted from merely safeguarding the moral status of humans to placing intrinsic value on animals as individuals" (NSPCA 2016:57) (emphasis added).

In its judgment, the Constitutional Court referred to an earlier judgment by the Supreme Court of Appeal ${ }^{28}$ :

The duty resting on us to protect and conserve our biodiversity is owed to present and future generations. In so doing, we will also be redressing past neglect. Constitutional values dictate a more caring attitude towards fellow humans, animals and the environment in general. (Lemthongthai 2016:20)

With these statements from the court ${ }^{29}$, the judiciary appears to have unambigu-

\footnotetext{
${ }^{25}$ As contained in Schedules 4 and 5 to the Constitution respectively.

${ }^{26}$ The Animal Protection Act of 1962 as amended.

${ }^{27}$ The Constitutional Court is the highest court in South Africa with 11 judges which preside over matters of a constitutional nature brought before them and are tasked with upholding the Constitution.

${ }^{28}$ The Supreme Court of appeal is the highest appeals court after the Constitutional Court.

${ }^{29}$ As well as other positive statements, such as Cameron JA's minority judgment in Openshaw which
} 
ously acknowledged the interaction (and more specifically, the interlinkages) between animals and their interests and human rights. This is not simply based on conservation of animals at a species level, but rather includes the consideration of individual animal's interests. Thus, in our consideration of the content of these human rights, animals and their interests must be considered, when they are impacted by same. This jurisprudence creates opportunities for the framing of future legal cases in relation to other rights, and the interests of animals (and I allege, the attainment of inclusive justice).

\section{The need for an integrational approach}

As the above cases illustrate, animals and their interests may be included in the scope of content of certain rights. However, taking it a step further, to the extent that such rights impact on or are impacted by them, animals and their interests can and should also be included in the achievement or realisation of such rights. Through this, human rights may be reinforced and strengthened, and the individual interests of animals may be respected and promoted.

If all law is required to be interpreted through a lens of constitutional values and constitutional values dictate a more caring attitude towards animals, then the lens through which we interpret rights must include a care for animals and their interests when same affects them. Once we acknowledge that animals have interests and that these interests impact on our interests, in the achievement of human rights, we cannot consistently limit our consideration to humans. Put differently, animals themselves must also be included as interested stakeholders ${ }^{30}$.

Turning now to some tangible examples of these overlapping and intersecting interests of animals and humans. For purposes of this Paper, I wish to briefly highlight two specific examples - the agricultural industry and the captive lion breeding industry ${ }^{31}$.

recognised that animals are worthy of protection not only because of the reflection that this has on human values, but because animals "are sentient beings that are capable of suffering and of experiencing pain" (National Council of Societies for the Prevention of Cruelty to Animals v Openshaw [2008] ZASCA 78; 2008 (5) SA 339 (SCA) (Openshaw 2008: 38).

${ }^{30}$ In my practice of animal law in South Africa, the concept of "interested stakeholders" is one which has arisen time and time again. Although this is applied to individual humans and organisations, I believe this term may be expanded to include animals in discussions/issues relating to them. This would include providing them with the necessary representation, among other resources. I would like to expand on this idea in future writings. A recent Constitutional Court case may be helpful in this regard, South African Veterinary Association v Speaker of the National Assembly 2019 (2) BCLR 273 (CC) at para 43 to the following effect: - "The more discrete and identifiable the potentially affected section of the population, and the more intense the possible effect on their interests, the more reasonable it would be to expect the Legislature to be astute to ensure that the potentially affected section of the population is given a reasonable opportunity to have a say."

${ }^{31}$ In a previous article I highlighted how issues overlap with animal and human interests (with some 


\section{The tragedy of $A g$}

\section{Background}

While entire books could be (and have been) written on the injustices of the animal agricultural industry, I have attempted to summarise a few particularly pertinent issues herein - specifically the interaction between the industry (characterised by mass animal suffering) and guaranteed constitutional rights.

In the USA specifically, this industry - tasked with the hugely important mission of feeding a nation - in many instances rather starves both animals and humans of their rights. It is the exemplar of commerce and economic interests trumping public interest. The current system not only supports mass institutionalised cruelty of billions of animals on a daily basis but causes huge environmental damage; contributes to climate change; infringes on the rights of workers in the industry; impacts surrounding communities (who are mostly vulnerable groups and people of color); and detrimentally effects human health (to name but a few) ${ }^{32}$. The legal system and government support industrialised animal agriculture, with the "objects” thereof (farmed animals) either specifically excluded from the definition of "animal" 33 in relevant legislation, or normal agricultural practices being exempted from cruelty legislation (Cassuto \& Cayleigh 2016). Furthermore, due to other laws, activists and others attempting to expose cruelty at factory farming (or other animal) operations can face criminal or civil penalties $^{34}$ (these are broadly referred to as "ag-gag" laws) or be branded as a "terrorist” (AETA 2006). Conversely, the industry receives economic ${ }^{35}$, political ${ }^{36}$, legal ${ }^{37}$, social and other forms of support and protection and in some instances, even immunity.

While ag-gag laws do not exist in South Africa, nor are farmed animals specifically

reference to industries) from a South African perspective. These range from Tourism and International Opinion; Violence and Crime; Racial Considerations; the Toxic Relationship with Food; Land; Family; and Corruption (Wilson 2019).

${ }^{32}$ Accordingly, the victims of this industry span a variety of factors: including species, races, locations, professions, and others.

${ }^{33}$ The Animal Welfare Act, the predominant piece of Federal legislation defines “animal”: “...but such term excludes other farm animals, such as, but not limited to livestock or poultry, used or intended for use as food or fiber, or livestock or poultry used or intended for use for improving animal nutrition, breeding, management, or production efficiency, or for improving the quality of food or fiber" (AWA $\S 2132(\mathrm{~g}))$.

${ }^{34}$ For further explanation see Marceau 2014.

35 Through various financial assistance including subsidies, profit protection, research and development, purchasing programs and otherwise. For more information on this see The Greenfield Project 2019.

${ }^{36}$ Campaign financing often comes from animal agricultural groups including the meat and dairy industry. See for example Open Secrets 2019.

${ }^{37}$ Through efforts that support and protect industry, harm activists, provide little transparency and otherwise. See for more information Animal Legal Defense Fund 2018. 
excluded from the primary animal protection act ${ }^{38}$, cruel animal practices occur on a daily basis and affect millions of animal (and human) lives.

These animals suffer in repulsive circumstances through practices that violate the most basic of considerations. The practices furthermore (i) infringe on guaranteed human rights and interests, (ii) have consequences that reinforce inequalities and fail to protect vulnerable members of society and (iii) are injurious to constitutional values.

\section{Rights and interests infringed}

Section 27 of the Bill of Rights states that everyone has the right to have access to (inter alia) sufficient food and water; and furthermore, that the state must "take reasonable legislative and other measures, within its available resources, to achieve the progressive realisation of each of these rights". Studies show (among other things) that animal products have a particularly large water requirement per unit of nutritional energy compared to food of plant origin, and that the production of meat requires and pollutes large amounts of water (Leenes, Mekonnen, Hoekstra: 2013).

Analysing this provision in more detail then, based on:

(i) Content: of these guaranteed rights (sufficient food and water)

(ii) Obligations: associated obligations on government (to achieve their realisation through reasonable legislative and other measures)

(iii) Status Quo: existing circumstances (the current and ongoing drought faced by the country)

(iv) Relevant factors: in the achievement of this right (animal agriculture is the confirmed highest use of fresh water ${ }^{39}$ in the country (WWF 2016)).

(v) Alternatives: other means to achieve the right (e.g. in this instance the provision of food/protein) that are less wasteful/harmful or otherwise preferable? (Reports that indicate that "meat, aquaculture, eggs, and dairy use $~ 83 \%$ of the world's farmland and contribute $56-58 \%$ of food's different emissions, despite providing only $37 \%$ of our protein and 18\% of our calories" (Poore and Nemecek 2018)).

Could a government that supports increased animal agriculture be said to be en route to achieving the progressive realisation of the right to water?

Then, continuing with the same industry but a separate guaranteed human right, the right to environment contained in section $24^{40}$, also contains provisions relating to the progressive realisation thereof by government. There are various studies illus-

\footnotetext{
${ }^{38}$ Although, certain animals are excluded from the definition of animal and the scope of the act and, notably, prosecutions for farmed animals in terms of this act are virtually non-existent.

${ }^{39}$ Cape Chameleon. 2018. The Water Footprint of What We Eat (https://capechameleon.co.za/the-waterfootprint-of-what-we-eat/).

${ }^{40}$ Section 24 reads: "Everyone has the right:...a. to an environment that is not harmful to their health or well-being; and b. to have the environment protected, for the benefit of present and future generations, through reasonable legislative and other measures that...i. prevent pollution and ecological degradation; ii. promote conservation; and iii. secure ecologically sustainable development and use of natural resources while promoting justifiable economic and social development."
} 
trating the harsh impact of current animal agricultural farming systems have on the environment (Clark \& Tilman 2017). Studies show that a further consequence of the intensive farming of animals is the huge amount of greenhouse gas emissions associated therewith (Poore and Nemecek 2018). As the association of increased greenhouse gas emissions impacts climate change and environment, could this industry and the support for it provided by government not be seen to be in direct contradistinction of its obligations to not only promote an environment that is not harmful to one's health but also the obligation to protect it for current and future generations ${ }^{41}$ ? Instead, we see government support and encouragement for these industries promoting increased production, and failure to deal with the huge externalities and hold industries accountable (even though the country has signed on to international treaties relating to curbing emissions).

If we take the above analysis and not only limit consideration to the rights and these factors but expand it to include the consideration of the interests of animals (and according to the Constitutional Court animal welfare forms part of the right to environment) - the argument in the achievement and realisation of these human rights because even stronger. It places even further obligations on government to re-examine and asses the status quo and consider the impact on an entirely different group. We then start to see how the consideration of animal interests may reinforce aspects of certain human rights, and opportunities are created to challenge the status quo, utilising the law, with all of these considerations in mind ${ }^{42}$.

\section{Reinforcing Societal and Economic Inequities and Divisions}

Apart from our blatant disregard for the other species impacted by this agricultural system, the current industrialised animal agricultural model has led to dire consequences and an unhealthy, unsustainable food system that disproportionately harms the most vulnerable and poorest human members of society. Two examples highlighted herein include climate change and human health. It has been well-documented that the effects of global warming (a major driver of which is animal agriculture) will be felt by poorer members of society: "While wealth and excess of the planet's rich drive the pollution responsible for global warming, it is the economically marginal that will be hardest hit by the environmental shocks that are the inevitable fallout of that pollution" (Goldenberg 2014).

From a human health perspective ${ }^{43}$, the poorer members of society often rely on

\footnotetext{
${ }^{41}$ Instead government supports increased animal agricultural operations, which include factory farming related practices such as veal crates, sow stalls and battery cages.

${ }^{42}$ Notably, and not mentioned in the section, there are other rights and interests impacted by current agricultural methods including but not limited to consumer protection and human health (such as the transfer of zoonotic diseases, the rise of antibiotic resistance development, and increased obesity rates and their distribution and marketing impacts on consumer protection rights (Wilson 2019).

${ }^{43}$ This is in addition to the various other harmful effects that animal-based proteins have been found to have on humans (such as the World Health Organisation declaring processed meats carcinogenic).
} 
lower grade meat as a source of protein. In 2017, South Africa had the largest outbreak of listeriosis ever recorded in history with over 1000 people being infected and 216 deaths $^{44}$ (Wilson 2019).

Workers in this industry are also victims, suffering from ailments including both physical and emotional ones such as post-traumatic stress disorder due to the work of slaughtering sentient animals repeatedly, day in and day out (Victor \& Barnard 2016).

\section{Anti-constitutional values}

Further to some of the constitutional values impacted by the industry aforementioned, it largely self-regulates on specific standards (including animal welfare), with voluntary norms and standards set by bodies composed mostly of industry players ${ }^{45}$.

Due to this, government has failed to promulgate proper regulation (which has checks and balances and requires specific processes to be followed), leading to a lack of accountability and oversight. This flies in the face of rights (such as just administrative action, contained in section 33 of the Bill of Rights), as well as constitutional values, including the elusive "culture of justification".

\section{Wildlife}

\section{In the [concrete] jungle - the lion sleeps tonight}

The intensive breeding of lions, and more particularly, the trade in lion bones is a loaded and hugely controversial topic. However, it presents another ideal example of overlapping human and animal interests ${ }^{46}$. More specifically, that by treating animals merely as commodities or cogs in this industry's wheel, with no consideration of their individual interests, human rights are clearly being violated as well as society more broadly ${ }^{47}$.

The trade itself permeates various levels in society and has political, legal, social, cultural, economic, ethical, racial and international implications ${ }^{48}$. Similarly to the

\footnotetext{
${ }^{44}$ Of these, $85 \%$ of the victims were black, $7 \%$ were coloured, $7 \%$ were white, and less than $1 \%$ were Asian. Notably, within these categories, most affected were the more vulnerable members of society children, pregnant mothers, the elderly, and those with compromised immune systems.

${ }^{45}$ For example, for pigs, only Voluntary standards exist which have been set by the "Livestock Welfare Co-ordinating Committee", the South African Pork Producers Organization, the Pig Veterinary Society and the NSPCA. These allow for gestation crates and farrowing crates which are largely considered cruel practices, which have been banned in various jurisdictions around the globe.

${ }^{46}$ Whilst there is a plethora of other issues with the industry, its placing here serves to illustrate a few overlapping human and nonhuman animal interests - outside of a domesticated animal context.

${ }^{47}$ While some of the considerations of rights impacted and infringed have been set out herein, there are others including (arguably) the constitutional right to environment (Section 24); fair administrative process; freedom of trade an occupation (Section 22); freedom from discrimination.

${ }^{48}$ I have previously written in detail of some of the legal and other issues relating to the captive lion bone breeding and trade - which should be consulted for a more detailed analysis on each of these lev-
} 
(domestic) animal agricultural example - thousands of animals suffer (needlessly) for this industry which is largely self-regulated, has major legal loopholes, enforcement issues and which lacks government oversight and accountability ${ }^{49}$ (Wilson 2019 Revelator).

In this instance, the demand is not for food (but rather largely entertainment) and is not domestically driven (but rather internationally) - however, the fruits similarly benefit very few (owners of these enterprises) but infringe on the rights and interests of many. Once again, the breeding of and trade in lions impacts the human right to environment, but notably it is the interpretation of this exact human right that has been utilised against animals. Through the emphasis on the words "sustainable...use of natural resources", government has enshrined their desolation and exploitation within the legal system.

On the economic side, the industry is having a major negative impact on the country's tourism, with a study indicating that as much as ZAR 56 billion in revenue could be lost if "business as usual continues" (Harvey 2018).

On the international front, the legal trade potentially fuels illegal trade, affects national security and wild lion (and other animal) populations and may include export of lion bones with tuberculosis to other countries (IWB 2017). Workers in the industry also face unsafe conditions handling wild animals, in many instances without the proper training and equipment.

The final and very important matter on this industry I wish to refer to is the lack of government accountability. Not only has the government failed to properly regulate this industry, and enforce laws where they do exist, the executive has actively ignored parliamentary committee resolutions (to shut down the industry) and failed to properly consult with the public. The previous Minister in charge of environment indicated that "If South Africa closes down the lion-breeding facilities and bans trade, there are more than 200 facilities and associated staff who will be negatively affected. In addition, thousands of lions will have no value and there will be no income" (EMS Foundation 2018).

All of the above however, is without mentioning of the fact that the large majority of the South African population finds the captive breeding of lions abhorrent and repulsive.

Importantly, a recent win was achieved in the courts by the NSPCA (the National Society for the Prevention of Cruelty to Animals), in relation to the determination of the 2017 and 2018 lion bone export quotas of South Africa (i.e. the number of lion skeletons the country may export each year - which is set by government). The NSPCA challenged the aforementioned quotas on various grounds including failure by government to consult and consider animal welfare. In the judgment, the High Court

els (Wilson 2019 Revelator).

${ }^{49}$ Recent horror stories of the state of lions kept at these facilities indicate that their welfare is of little concern. This is particularly relevant when the lions are being utilised in the lion bone trade, who do not need to appear healthy (compared with lions utilised for trophy hunts who need to appear healthy so they may be displayed after their death). 
stated:

When one then has regard to the connection between welfare interests of animals and conservation as reflected in the judgments of both the Supreme Court of Appeal and the Constitutional Court in Lemthongthai and NSPCA respectively, then it is inconceivable that the State Respondents could have ignored welfare considerations of lions in captivity in setting the annual export quota. (NSPCA v Minister of Environmental Affairs 2019: 74)

The judgment ${ }^{50}$ re-emphasized the need to consider animal interests in decisions affecting them, as well as government accountability for failure to do so. This judgment together with those aforementioned, open the door for some opportunities to challenge the injustices relating to human and nonhuman animals in future.

\section{THE PROBLEM OF ANIMAL RIGHTS}

“That's beyond our borders. You must never go there Simba.”- Mufasa

\section{Animal Rights in South Africa}

Post-apartheid, the focus of the South African legal system and many cases brought have been on the advancement of human rights and attempting to rectify the effects of hugely repugnant laws and policies of the past. Accordingly, it is not surprising why nonhuman animals have largely been left out of this discourse. Aside from the lacuna in the legal system, there are a number of other issues that complicate the landscape in the potential achievement of this approach. While these are outside the scope of the paper, two worth mentioning without further explanation herein include the lack of capacity and resources, and the role of African ethics and culture.

Two issues which I wish to delve in slightly more detail (albeit not fully) include racial considerations, and conflict of rights generally. While these are extremely complex matters which require much more detailed consideration, I have highlighted these in an attempt to open these for further discussion in future.

\section{Racial Considerations}

In South Africa, animal rights activism efforts are largely considered an issue driven by white middle class (mostly women). This perception (or reality) has (I believe) marginalised previously disadvantaged individuals from joining the movement. This perception has not been abetted by efforts exclusionary of human rights considerations. For example - animal activists may be extremely outraged and vocal about such outrage where a rhino is killed for its horn but may be silent about the death of (one or multiple) rangers in armed conflicts with poachers. As previously mentioned, they may even celebrate the death of a poacher and accompany this with a racial slur. This and other actions, reinforces a widely held view that wild animals receive more

\footnotetext{
${ }^{50}$ Although moot given the fact that the challenged export quotas had already been fulfilled when the case was heard.
} 
concern than black people living in rural communities.

As one of the (highly controversial) political opposition leaders put it:

One only needs to look at how cheap a black life truly is to white people by comparing the fact that 34 black mineworkers are massacred in broad daylight, and white people never even run a petition online. This tells you, right here in South Africa, a country with a majority of blacks, that black people are worth less than rhinos. Here, you find that the dogs and cats of white people have medical aid, while the black garden and kitchen workers do not and cannot afford it (Malema 2016).

Another, albeit differently themed statement by former (then) president of South Africa, Jacob Zuma in his first speech since being re-elected, indicated that having a dog is "un-African" - that spending money on buying a dog, taking it to the vet and for walks belonged to white culture and was not the African way, which was to focus on the family (Hans \& Moolla 2012). The same news report paraphrased that "Instead, a person lost dignity and ubuntu, and was also likely to lose respect and love for his fellow human beings" (Hans \& Moolla 2012).

The above sentiments importantly place human rights and animal rights in direct contradistinction with one another and illustrate the failure to recognise the interlinkages between the two. It serves only to divide and separate by associating care for animals with a neglect for humans, accompanied by a racist narrative.

Interestingly, from another black activist's perspective (albeit from America - but who represents a growing movement of people of colour to recognise overlapping oppressions), Syl Ko explains:

The racial hierarchy and racism, not to mention the racial thinking it generates, was the novel way white, Western Europeans in the colonial period legally and morally placed groups outside the "human" zone. As a result, the authors of this system were deeply invested in a rigid species divide where "human" indicated the domain of morality and the law, and "animal was a space of absence of being and lawlessness inviting a need to be controlled, disciplined and contained by “humans" (Ko 2017: 46).

It is clear to me that if we truly want to take white supremacy, racism and coloniality (however one wants to talk about it) to task, then we need to do the same to the continuing, uncontroversial view that "the animal" is the opposite status marker to “the human” (Ko 2017: 47).

Recognising similarities between the racial divide and human/animal divide, Ko rejects these divisions as well as the system of oppression accompanying them.

\section{Conflicts/Limitations}

Another potential challenge to including animal interests in our scope of consideration or the interpretation of certain rights, is that this may appear to place clear limitations on human rights. For example, the human rights to freedom of religion, belief and opinion and the right to language and culture: in many instances, religious and 
cultural practices involve ritual slaughter and other uses of animals, which would inevitably conflict with an animal's interest in a right to life. It may arise in the context of the humans right to property: given the current legal status of animals as property, ones rights to do with ones property as one wishes would undoubtedly be impacted. Similarly, in the context of the right to freedom of trade and occupation: where animal use (alive or dead) forms the basis of such occupations/trade and employment.

Whilst this Paper does not present a solution to this dilemma, it suffices (for now) to say that human rights conflict with other human rights all the time, these are adjudicated on and weighed and balanced. Furthermore, taking into account relevant factors and principles, such as the principle of proportionality and reasonableness, rights may be limited. It is largely the task of the judiciary to adjudicate on these, in accordance with the relevant procedures ${ }^{51}$.

As aforementioned, the mere fact that rights and interests' conflict are not an argument against considering or granting them, ab initio.

\section{LOOKING AHEAD: A JUST SOCIETY}

Animal Rights as a social justice issue

"Out of the ashes of this tragedy, we shall rise to greet the dawning of a new era." - Scar

Recognising the overlap of interests and the non-realisation of guaranteed fundamental human rights - the inclusion of animal interests in our scope of consideration should increasingly be considered an issue of social justice.

Jones argues that:

(...) the philosophical foundations for establishing robust moral status and moral entitlements for nonhuman animals are sound; that these moral entitlements make other-than-human animals proper and legitimate subjects of justice; and, from the fact that nonhuman animals suffer systemic and institutional domination and oppression, it follows that animal rights are a social justice issue (Jones 2015: 467).

He provides a solid philosophical basis why non-human animals should be included in our consideration and strivings for justice and why animal rights are a social justice issue.

Ko further explores the interlinkages of oppression, through the example of racism "We think that something crucial has been missing from most discussions about racism and from almost all strategies to resist or combat racism: the situation of animals" and goes further - "there is an open acceptance of the negative status of "the animal"... Which... is a tacit acceptance of the hierarchical racial system and white supremacy in general". The human-animal divide is the ideological bedrock underlying the framework of white supremacy. The negative notion of "the animal" is the anchor of this system". In essence we need to "actively de-link ourselves from Eurocentric, white-su-

\footnotetext{
${ }^{51}$ Section 36 of the Bill of Rights provides specifically for the limitation of rights and the factors to be considered in this process.
} 
premacist ways of thinking” (Ko 2017).

With these ideas, Ko acknowledges how the divide between animals and humans, specifically with regard to racial issues, has anchored a colonial system and has assisted in reinforcing injustices. If this argument is acceptable, then in some instances the victims of human rights violations and animals have a common enemy as such, a system (and those who perpetuate it) built on domination, inequality and oppression (and even exploitation, violence and the like).

Gorski highlights corporate interests as the common tangible enemy:

The worst human rights offenders, systematically speaking, are the worst animal rights offenders and the worst environmental offenders. Yes, there are individual oppressors of people, animals, and the environment. But when I consider local, national, and global systems of power-the kinds of systems which can socialize masses of people to comply with, or ignore, certain practices and policies or which have the economic sway to pressure the state into sponsoring (such as by loosening regulations on) these abuses-what I find is the same, regardless of whether I'm targeting animal, human, or environmental injustice: corporate interests (Gorski 2009:2).

These ideas illustrate how the separation ideology (and "othering”) which allows the systems of oppression to flourish, benefits only the oppressors and their interests. At the same time, disempowering the victims and ensuring the continuation of their suffering. Thus, only through the dismantling of this separateness may the victims of such oppression (as well as society more generally) gain empowerment.

\section{Legal Context}

Transitioning from practical examples and philosophical ideals to what material change may look like in law and policy. As with many governments, South Africa operates through the separation of powers doctrine with three branches of government being the legislative (lawmakers); executive (implementation and agency bodies) and the judiciary (courts and adjudication bodies). Unfortunately, the legislature has done little to improve protections for animals - even efforts to ban the cruel testing of cosmetics on animals initiated in 2017 have yet to come to fruition ${ }^{52}$.

The executive departments within whose mandate animals fall appear to have a very clear idea of how animals should be treated - which unsurprisingly, seeks to promotes their use and commodification over consideration of their individual interests or well-being. Earlier this year, the ambit of the act that provides for "the breeding, identification and utilisation of genetically superior animals in order to improve the production and performance of animals in the interest of the Republic" was extended to include certain wild animals, effectively enshrining the domestication of wild animals for various uses similar to agricultural animals (Animal Improvement Act 1998).

Accordingly, it may be that the judiciary is the only branch of government that may have an impact in improving the protection of animal (and in so doing, humans).

\footnotetext{
${ }^{52}$ Even then, this legislation was introduced by means of a private member’s Bill.
} 
While the judiciary does not have carte blanche to interpret either the Constitution or legislation in an unreasonable way and there are very strict checks and balances, it is submitted that through strategic litigation and creative lawyering - the door may be opened for material change to occur. If cases are presented in such a way that courts may properly consider the interests of both human and nonhuman animals and interpret the Constitution or other laws in line with this and the relevant constitutional values, the common law may be developed ${ }^{53}$. Such cases challenging legislation and practices should include scientific and well-reasoned arguments and potential alternatives ${ }^{54}$.

In preparation for this, sensitisation to the integrational approach and animal rights as a social justice issue needs to occur at various levels: including law students and lawyers, human rights activists, animal rights activists and educators ${ }^{55}$. Lawyers must be sensitised in law school ${ }^{56}$, and in practice to allow a holistic view in their work (whether this is in private practice, for non-profits or otherwise).

In a similar vein, human rights and animal rights activists and organisations should be sensitised to the plights and efforts of each other. When the opportunity arises, in litigation one may support the efforts of the other by filing amicus briefs, or even jointly filing or defending litigation. Similarly, when there are calls for public comment on legislation and policy that affect both, efforts and resources may be enjoined to the extent feasible.

\section{"Sometimes what's left behind can grow better than the generation before."- Simba}

While the inclusion of the consideration of animals' interests may not solve all of the major human rights violations occurring today, a change in approach is unequivocally

\footnotetext{
${ }^{53}$ In S v Mhlungu Sachs J explained this ever-changing process of interpretation as follows: I regard the question of interpretation to be one to which there can never be an absolute and definite answer and that, in particular... how to balance out competing provisions, will always take the form of a principled judicial dialogue, in the first place between members of this court, then between our Court and other Courts, the legal profession, law schools, parliament, and indirectly, with the public at large ( $\mathrm{S} \mathrm{v}$ Mhlungu).

${ }^{54}$ One example may be the interpretation of the term "sustainable use" contained in the environmental right of the Constitution - which the executive has interpreted in the context of wildlife to mean consumptive use of animals.

${ }^{55}$ Humane education in the traditional sense is simply not enough (and is not even legislatively mandated). Education should and needs to be holistic in the sense that children should be taught about their actions and behaviours and the broader impact that these have. After all, it is their future that is being compromised and they will suffer the ill-effects of the actions of the generations before them.

${ }^{56}$ Many well-respected law schools around the world are including animal law in the curriculum with over 187 schools in the USA teaching this in some form. Additionally, the growth of animal law clinics, where law students get practical experience working in this realm has proven successful, including two at Lewis \& Clark Law School and Harvard Law School recently joining the ranks of schools offering this option.
} 
necessary.

It is evident throughout history that systems based on the practices of asserting dominance, emphasising differences and promoting separateness have led to horrific consequences. Only now are we starting to realise the consequences of our actions relating to our treatment of animals - including the sixth mass extinction and climate change.

In delivering the judgment for the 2016 NSPCA Constitutional Court case, Justice Khampepe stated:

From the ancient Khoisan reverence of the eland to the contemporary conception of the dog as “man's best friend”, humans and animals have a storied relationship, one that is a part of the fabric of our society, homes and lives. Animals have shifted from being "mere brutes or beasts" to "fellow beasts, fellow mortals or fellow creatures" and finally to "companions, friends and brothers" (NSPCA 2016).

The abovementioned statement indicates the interwovenness between human animals and nonhuman animals, and our capacity to be companions, friends and even brothers. If all beings are all threads composing one tapestry - it is currently on fire ${ }^{57}$.

This sentiment has been echoed in other ways - by the previous South African President when announcing the Interim Constitution stated:

At times, and in fear, I have wondered whether I should concede equal citizenship of our country to the leopard and the lion, the elephant and the springbok, the hyena, the black mamba and the pestilential mosquito. A human presence among all these, a feature on the face of our native land thus defined, I know that none dare challenge me when I say - I am an African! (Mbeki 1994).

While narratives tend to indicate that animal and human rights are a zero-sum game, a recent Harvard study found that support for animal rights was also correlated with support for LGBT individuals, racial and ethnic minorities, unauthorized immigrants, and low-income people (Klein 2019).

Thus, if we understand that violence, ${ }^{58}$ injustice, oppression and the like do not occur in a vacuum - in the pursuit of combatting these - we cannot allow the culture of separateness to disempower us. Regardless of oppressor or the oppressed, "injustice anywhere is a threat to justice everywhere" 59 - and thus systems promoting this must be dismantled through all tools necessary. It is only through recognition of our to-

\footnotetext{
${ }^{57}$ Ironically, at the time of writing this - so is the earth, with record-breaking wildfires raging across parts of South America as well as Australia.

${ }^{58}$ We also understand that violence against humans doesn't occur only in relation to humans. A well-emphasised often utilised example is that of "the link". There is a large body of research on this and it should be consulted for further examples of interlinking human and animal interests.

${ }^{59}$ Martin Luther King Jr., Letter from the Birmingham Jail 16 April 1963. In the same letter he wrote: "We are caught in an inescapable network of mutuality, tied in a single garment of destiny. Whatever affects one directly, affects all indirectly. Never again can we afford to live with the narrow, provincial 'outside agitator' idea".
} 
getherness can we begin to empower ourselves and claim a just and equitable society for all who live in it.

Sophisticated democracies and movements require an integrational approach. By expanding the scope and interpretation of human interests to include the consideration of animal interests; and through coordinated, targeted efforts - we may ensure that the notion of justice is achieved, for all who require it.

FUNDING: This research received no external funding.

CONFLICT OF INTEREST: The author declares no conflict of interest.

ACKNOWLEDGEMENTS: I would like to thank Professor David Bilchitz and Professor Bonita Meyersfeld for their comments on this Paper. Together with Professor Kathy Hessler, their mentorship and tireless work over decades for both human and nonhuman animals have inspired me to find my voice.

\section{REFERENCES}

Animal Enterprise Terrorism (AETA). 2006. (Pub.L. 109-374; 18 U.S.C. § 43). (USA)

Animal Improvement Act, Act 62 of 1998 (South Africa).

Animal Legal Defense Fund. 2018. "2018-2020: Farmed Animals \& the Law Student Chapters Program Guide.” ALDF Website. Retrieved September 8, 2019 (https://aldf.org/article/student-animal-legal-defense-fund-saldf-programguides/2018-2020-farmed-animals-the-law/).

Animal Protection Act, Act 71 of 1962 (South Africa).

Animal Protection Amendment Act. 2017. (South Africa).

Animal Welfare Act (Laboratory Animal Welfare Act).1966. (P.L. 89-544 §2132).

Baker, Aryn. 2019 "What South Africa Can Teach Us as Worldwide Inequality Grows." Time. 2019. Retrieved September 10, 2019 (https://time.com/longform/south-africa-unequal-country/).

Bilchitz, David. 2017. "Exploring the Relationship between the Environmental Right in the South African Constitution and Protection for the Interests of Animals." South African Law Journal 134(4): 740-777. DOI: http://dx.doi.org/10.2139/ ssrn.2942112

Bilchitz, David. 2009. "Does Transformative Constitutionalism Require the Recognition of Animal Rights?” Southern African Public Law 25(2): 267-300. Retrieved September 10, 2019 (https://ssrn.com/abstract=1872936).

Bilchitz, David. 2010. "Does Transformative Constitutionalism Require the Recognition of Animal Rights?” Southern African Public Law 25(2): 267-300. Retrieved September 10, 2019 (https://hdl.handle.net/10520/EJC153243).

Department of Environmental Affairs. 2019. "Minister Mokonyane moves to address concerns on captive lion breeding and associated trade activities." Retrieved 20 August 2019 (https://www.environment.gov.za/mediarelease/mokonyane_captivelion_nspca).

Cassuto, David N. and Cayleigh Eckhardt. 2016. “Don’t Be Cruel (Anymore): A Look at the Animal Cruelty Regimes of the United States and Brazil with a Call for a 
New Animal Welfare Agency.” Boston College Environmental Affairs Law Review 43(1): 1-43. Retrieved 20 August 2019 (http://lawdigitalcommons.bc.edu/ealr/ vol43/iss1/2).

Clark, Michael and David Tilman. 2017. "Comparative analysis of environmental impacts of agricultural production systems, agricultural input efficiency, and food choice.” Environmental Research Letters 12(6): 1-11. Retrieved July 20, 2019 (https://iopscience.iop.org/article/10.1088/1748-9326/aa6cd5/meta).

Colvin, Christine, Muruven, Dean, Lindley, David, Gordon, Helen and Schachtschneider, Klaudia. 2016. "Water: Facts and Futures, Rethinking South Africa's Water Futures.” WWF. Retrieved September 9, 2019. (http://awsassets.wwf.org.za/ downloads/wwf009_waterfactsandfutures_report_web_lowres_pdf.).

Constitution of the Republic of South Africa. 1996.

Disney. 2019. The Lion King. 2019. (https://movies.disney.com/the-lion-king-2019).

The Economist. 2017. "South Africa has one of the world's worst education systems." Retrieved August 20, 2019 (https://www.economist.com/middle-east-and-africa/2017/01/07/south-africa-has-one-of-the-worlds-worst-education-systems).

EMS Foundation. 2018. “Announcements, Tablings and Committee Reports No 167-2018 No 167-2018 Fifth Session, Fifth Parliament of the Republic of South Africa Announcements, Tablings and Committee Reports Tuesday, 13 November 2018.” Retrieved August 20, 2019 (https://emsfoundation.org.za/wp-content/ uploads/Parliament-of-the-RSA-Announcements-Tablings-and-Committee-reports.pdf).

ESCR. 2019. “Introduction to Economic, Social, and Cultural Rights.” Retrieved August 18, 2019 (https://www.escr-net.org/rights).

Gerbens-Leenes, P. Winnie and Mesfin M. Mekonnen and Arjen Y. Hoekstra. 2013. "The Water Footprint of Poultry, Pork and Beef: A Comparative Study in Different Countries and Production Systems.” Water Resources and Industry 1-2: 2536. https://doi.org/10.1016/j.wri.2013.03.001

Goldenberg, Suzanne. 2014. “Climate change: the poor will suffer most.” The Guardian, March 30, 2014. Retrieved July 20, 2019 (https://www.theguardian.com/environment/2014/mar/31/climate-change-poor-suffer-most-un-report).

Gorski Paul C. 2009. "Critical Ties: The Animal Rights Awakening of a Social Justice Educator.” Edchange Website. Retrieved August 21, 2019 (http://www.edchange. org/publications/animal-rights-social-justice.pdf).

Government of the Republic of South Africa and Others v Grootboom and Others (CCT11/00) [2000] ZACC 19; 2001 (1) SA 46; 2000 (11) BCLR 1169 (4 October 2000).

Greenfield Project. 2019. Greenfield Website. Retrieved August 22, 2019 (https://www. thegreenfieldproject.org/).

Harvey, Ross. 2018. "The Economics of Captive Predator Breeding in South Africa." SAIIA. Retrieved August 22, 2019 (https://saiia.org.za/research/picking-a-bonewith-captive-predator-breeding-in-south-africa/).

Hans, Bongani and Moolla, Yusuf. 2012. "Pet dogs not for blacks - Zuma.” IOL. Retrieved August 20, 2019 (https://www.iol.co.za/news/politics/pet-dogs-not-for- 
blacks-zuma-1445123).

Interim Constitution of the Republic of South Africa. Act No. 200 of 1993 (South Africa).

IWB. 2017. “International Wildlife Bond Letter to SA High Commissioner UK 'Captive' Bred Lions and the Tuberculosis (TB) Risk to Human Health.” Retrieved August, 232019 (https://iwbond.org/wp-content/uploads/2017/08/IWB_Letter-RSA-Embassy_14-August-2017.pdf).

Jones, R. C. 2015. "Animal rights is a social justice issue." Contemporary Justice Review 18(4): 467-482. Retrieved August, 232019 (https://animalstudiesrepository.org/ anirmov/9/).

Klein, Ezra 2019. “There's no conflict between human and animal rights.” Vox, August 21, 2019. Retrieved August, 232019 (https://www.vox.com/future-perfect/2019/8/21/20812623/animal-rights-suffering-singer-compassion).

Ko, Aph and Syl Ko. 2017. Aphro-Ism: Essays on Pop Culture, Feminism, and Black Veganism from Two Sisters. Brooklyn, NY: Lantern Books.

Kotzé, Louis J. 2014. "Human rights and the environment in the Anthropocene." The AnthropoceneReview1(3):252-275.DOI:https://doi.org/10.1177/2053019614547741

Malema, Julius. 2016. "Why do white people despise blacks?” Timeslive, January 10, 2016. Retrieved 22 August 2019. (https://www.timeslive.co.za/sunday-times/ opinion-and-analysis/2016-01-10-why-do-white-people-despise-blacks/).

Marceau, Justin. 2014. “Ag Gag Past, Present, and Future.” Seattle University Law Review 38(4)" 1317-1344.

Mbeki, Thabo. 1996. “I am African.” SA People. Retrieved August 11, 2019 (https:// www.sapeople.com/2016/05/25/i-am-an-african/).

Mureinik, Etienne. 1994. "A Bridge to Where? Introducing the Interim Bill of Rights." South African Journal on Human Rights 10(1): 31-48. DOI: https://doi.org/10.10 $\underline{80 / 02587203.1994 .11827527}$

National Society for the Prevention of Cruelty to Animals v Minister of Justice and Constitutional Development and Another. 2016. (CCT1/16) [2016] ZACC 46; 2017 (1) SACR 284 (CC); 2017 (4) BCLR 517 (CC) (South Africa).

National Council of The Society for Prevention of Cruelty to Animals v Minister of Environmental Affairs and Others (86515/2017) [2019] ZAGPPHC 367; [2019] 4 All SA 193 (GP) (South Africa).

Open Secrets. 2019. Website. Retrieved August 23, 2019 (https://www.opensecrets. org/industries/indus.php?Ind=A).

Poore, Joseph and Thomas Nemecek. 2018. "Reducing food's environmental impacts through producers and consumers” Science 360 (6392): 987-992. DOI: doi: 10.1126/science.aaq0216

R v Moato.1947. (1) SA 490 (South Africa).

S v Acheson.1991. (2) SA 805 (NM) (South Africa).

S v Mhlungu and Others (CCT25/94).1995. ZACC 4; 1995 (3) SA 867; 1995 (7) BCLR 793 (CC). (South Africa).

Shabalala and Others v Attorney-General of the Transvaal and Another. 1995. (CCT23/94) [1995] ZACC 12; 1995 (12) BCLR 1593; 1996 (1) SA 725 (South Africa). 
The Universal Declaration of Human Rights. 1948. UN General Assembly. Retrieved August 15, 2019 (https://www.un.org/en/universal-declaration-human-rights/).

University of the Free State. Undated. Retrieved August 20, 2019 (http://earning. ufs.ac.za/ULL214_OFF/Resources/2.\%20RESOURCES/2.\%20Study\%20material/2.\%20\%20English\%20Guide/11.pdf).

Victor, Karen and Antoni Barnard. 2016. "Slaughtering for a living: A hermeneutic phenomenological perspective on the well-being of slaughterhouse employees." International Journal of Qualitative Studies on Health and Well-being 11: 30266. DOI:10.3402/qhw.v11.30266

Wilson, Amy P. 2019. "Animal Law in South Africa: Until the lions have their own lawyers, the law will continue to protect the hunter." $d A$. Derecho Animal (Forum of Animal Law Studies) 10(1): 35-58. DOI: https://doi.org/10.5565/rev/da.399

Wilson, Amy P. 2019. “South Africa's Fallen Pride: How Law and Government Fail to Protect Lions.” The Revelator. Retrieved August 22, 2019 (https://therevelator. org/lion-hunting-south-africa/).

Young, Katharine G. 2017. "Proportionality, Reasonableness, and Economic and Social Rights.” Proportionality: New Frontiers, New Challenges, forthcoming (2017).

\section{BIOGRAPHICAL NOTE}

Amy P. Wilson is director and co-founder of Animal Law Reform South Africa and the Aquatic Animal Law Initiative Fellow at the Center for Animal Law Studies at Lewis \& Clark Law School, USA.

OPEN ACCESS: This article is distributed under the terms of the Creative Commons Attribution Non-commercial License (CC BY-NC 4.0) which permits any non-commercial use, and reproduction in any medium, provided the original author(s) and source are credited. 
